\title{
Comparison of the Cartoons Created by the Gifted and Non-gifted Students
}

\author{
Ahmet Kurnaz ${ }^{1, *}$, Mehmet Ali Genç ${ }^{2}$ \\ ${ }^{1}$ Department of Special Education, Necmettin Erbakan University, Turkey \\ ${ }^{2}$ Department of Art Education, Necmettin Erbakan University, Turkey
}

Copyright $\bigcirc 2017$ by authors, all rights reserved. Authors agree that this article remains permanently open access under the terms of the Creative Commons Attribution License 4.0 International License

\begin{abstract}
When compared to their non-gifted peers, gifted students who have high-level talent, motivation and creativity are significantly different from other students in many respects. In addition to their distinct mental, physical and educational features, developed sense of humor is another distinct feature of these students. Also, currently no literature has been published regarding the effect of being giftedness on cartoon drawing. So, the purpose of this study was to compare the ability of gifted and non-gifted students in cartoon-drawing practices and reflection of humor in their drawings. This paper reports the results of a study conducted through survey method and case study as one of the qualitative research method. 59 gifted and non-gifted students participated in the study. Participants were selected through deviant case sampling and convenient sampling. Data was collected through cartoons and analyzed through document analysis. In order to gather data, participants were asked to draw a cartoon related to a certain situation and jokes. Three experts, according to the assessment scale, evaluated cartoons drawn by both groups, and students' cartoon scores, drawing and humor scores were compared by analysis of the evaluation results. Data showed that skills of creating, drawing and reflecting humor to the cartoons of gifted students were at medium level, and those of non-gifted students were insufficient. Gifted students were successful at the same level in creating cartoons based on a situation and a funny, and in drawing and reflecting humor to cartoons. Also, it was seen that non-gifted students were more successful at creating cartoons based on a funny than a situation.
\end{abstract}

Keywords Gifted, Drawings, Humor, Situation and Cartoons, Jokes and Cartoons Figure, Manuscript Format

\section{Introduction}

Gifted students, who are extremely rare in society, are of vital importance in in the future of societies as they have growth rates, characteristics and potential, which are different from typical children. Gifted individuals, who draw attention in every society, are defined as children and adolescents who have intellectual, creative, and artistic leadership capacity or who over perform in specific academic fields, and who require special education and activities which are not provided by the schools [1]. Adding the task commitment to the proposed description of giftedness, Renzulli [2] articulates that three clusters such as above-average ability, creativity and high levels of task commitment (motivation) exist together and the interaction among these three clusters refers to the giftedness.

The distribution, frequency, timing and composition of some characteristics pertaining to gifted individuals differ [3]. Many educationalists have produced lists showing the characteristics of the gifted children. According to common findings of the studies conducted, it is seen that they are well ahead of their peers in terms of physical, mental and learning traits considering the general characteristics of the gifted children [4].

Common findings obtained from the studies conducted reveal that gifted children are well ahead of their time considering their general characteristics [5]. As children are successful in areas related to general knowledge level and general mental ability [6], their mental aspects or talent precede their bodies. The most obvious learning characteristics of gifted students who have different learning needs from those of their peers are that they have the ability to learn quickly. With a voracious curiosity, gifted students always struggle to learn about new things [7]. They develop earlier than their peers physically and mentally [8]. Besides holding strong opinions and thoughts, they come up with solutions to problems quickly by producing unusual and original ideas towards problem-solving [9]. They think clearly, develop their relationships easily, transfer their knowledge, and they can use them in the most appropriate way in new situations [3]. In addition to these specified traits, one of the most striking characteristics of gifted students is that they have a well-developed sense of humor. Gifted students who enjoy 
jokes and using witty saying [10] often have the ability to understand jokes and humor maturely, and to see the funny side of something and its strangeness. They learn to make mature and funny jokes and enjoy them, and use appropriate humor at an early age [3]. As they have a keen sense of humor [11], they easily recognize fine jokes that ordinary people cannot recognize. With the development of their aesthetics emotions, they are involved in aesthetics features by noticing aesthetics features quickly [12].

It is possible to define the concept of drawing (cartoon), one of the tools for humor, in different forms [13]. According to McBride and Verbeck [14], a cartoon is the unreal description of a character through exaggeration in order to make him/her arouse admiration, awareness and desire. According to what Seçgin et al., [15] quote, cartoons "are arts of transforming ridiculous aspects that contrast with the natural ones or contradict with the ordinary of humans, creatures, events and even feelings and thoughts into humorous expressions using exaggerated illustrations (sometimes supported with a text)". Cartoons are works of art that could appeal to all age groups, and include amusement, laughter, satire (criticism), thinking and visuality. Thus, the reason why cartoons are widely used is that they can convey their messages or ideas in a more comfortable, visual and amusing way [16].

Besides being amusing, cartoons are also powerful tools for advising and learning. Children who first concentrate on the line in the cartoon then think over every detail. They make comments by establishing a connection, and weave a story in their minds by detecting differences and similarities between objects [15]. Cartoons consist sometimes of pure line drawings, and sometimes of speech and line drawings. A topic, which is covered in written in so many words, is described using three or five lines in a cartoon [17].

The key element of cartoon is imagination [13]. Another characteristic of gifted children is that they have a larger imaginary world. During the process of drawing cartoon, the individual develops his/her imagination by interacting with his/her surroundings, explores through his/her own experiences and finds new and different ways of learning. $\mathrm{He} / \mathrm{she}$ develops a humorous point of view, produces new and original ideas, builds new relationships and reveals different perspectives [13].

Humor also exists between the customs and traditions, lifestyles, history and moral values that societies have accumulated from their past and it occupies an important place [18]. It can be said that there is a natural connection in terms of humor between cartoon and joke, short story, novel, theater, poetry and essay etc. from literary genres in which humorous expression comes to the fore. This connection makes it possible for some of the humorous stories (jokes of Nasreddin Hodja etc.) to be cartooned between the two genres [17].

Humorous stories of Nasreddin Hodja, a humorist, continue to maintain their values for centuries [18]. In this study, gifted and non-gifted students were asked to create a cartoon based on 'Laying flour on rope and 'April Fool's joke', two of the Nasreddin Hodja's jokes, in order to compare their sense of humor. The created cartoons were evaluated in terms of humor and aesthetics.

Despite the fact that there have been enough studies in the related literature conducted to determine the use of cartoons as a tool in education or the contribution of cartoons to teaching process [19-23], no studies have been found regarding students' levels of creating cartoons. This situation makes the current study more important.

Education of gifted students is conducted in institutions called 'Science and Art Centers' in Turkey. First, second and third grade primary school students studying in formal education are observed by their classroom teachers and the eligible ones are nominated for the diagnosis process. After the recommendation of classroom teachers, basic ability tests are applied as the group general mental ability test. And later the individual intelligence test is applied [24].

In the general ability test (group scanning), students' language, shape-space, deduction, discrimination, numerical and general abilities are measured [25]. Group test results are not considered as a definite diagnostic tool, although they help sort a group in terms of their ability levels. Thus, an individual assessment is conducted to determine the definite diagnosis of the most successful rate in the group test [26]. During this stage, Wechsler Intelligence Scale for Children (WISC-R), one of the individual intelligence tests, is administered to students. The WISC-R measures abilities based on verbal cognitive performance and give a full scale IQ of 100, with a standard deviation of 15 . The ones more than two standard deviations above the average in this test (130 and above) are considered 'gifted' [3]. Nevertheless, there is no assessment method to identify students' creativity levels within the process of determining the giftedness in Turkey. In the identification process of students with special talents, these students were taken into group evaluation process in terms of visual arts. However, none of them had the right to be taken into individual evaluation process in visual arts.

Students identified as gifted get the right to register to Science and Art Center and they have support education at these centers in addition to their formal education. Science Art Centers, which provide support education without taking the students out of their peers [27], have a five-stage educational program. These stages are adaption program, support education program, realizing individual skills program, improving special skills program and project production program.

\subsection{Purpose of the Study}

This study aims to investigate the levels of creating cartoon, drawing skills and levels of using humor in the cartoons of the gifted and non-gifted students and whether they create a better cartoon through jokes or a situation. For 
this purpose, skills of the gifted and non-gifted students at fourth grade level of primary school related to creating cartoons, reflecting humor to the cartoons and drawing both situation-based and joke-based cartoons were examined.

\section{Methods}

This study was conducted through survey model and case study as one of the qualitative research methods has been used. Case study aims to reveal results regarding a certain case. Finding how some variables regarding a case such as environment, individuals, events and processes affect that case is the major feature of the case study. [28, 29]. This study aims to find out how IQ levels of individuals affect their cartoon drawing skills. 59 gifted and non-gifted students participated in the study. Participants were selected through deviant case sampling and convenient sampling.

The study was conducted based on the data obtained through the scoring of the cartoons that the gifted and non-gifted students created at the end of the joke and situation given to them.

\subsection{Study Group}

Participants of the study were selected through deviant case sampling and convenient sampling which are the purposeful sampling methods used in qualitative researches. In deviant case sampling groups which have a certain qualification or performance at extremely high or low levels are selected $[28,30]$. As it is considered that the cartoon drawing ability of gifted and non-gifted students would be different from each other, participants of this study consist of gifted and non-gifted students with this aspect, since gifted and non-gifted students have a certain qualification and performance at extremely high or low levels, and the deviant case sampling was applied in this study.

In identifying gifted and non-gifted students who are participated in the study, convenient sampling method has been used. This sampling method makes the research faster and more practical and it is easier to reach the group $[28,31]$. In Turkey, applying IQ test to the students is both difficult and impossible by individual efforts. Identification must be done by official institutions. So participants are chosen among the students who have been applied IQ test by Ministry of Education.

The gifted students consisted of 15 female and 15 male participants attending Konya Science and Arts Center, the only institution giving education for gifted students, adaptation period (Primary school 4th grade) in the fall semester of the academic year 2013-2014. IQ scores of 30 gifted students participated in the study are between $130-$ 148 WISC-R IQ score and their average IQ score is 138.
Because of the ethical issues, students' individual IQ scores were not made available in the study. Data were collected during the very first month of the support education process provided for gifted students. That is, the survey was carried out at the beginning of the education process and the students had not completed the support education yet at that time.

Non-gifted students consisted of 13 female and 16 male participants attending 4th grade at a primary school in Konya/Selçuklu in the fall semester of the academic year 2013-2014. The average WISC-R IQ score was 118 with a range from 112 to 127 . A total of 30 students attending Science and Art Center, the only institution giving education for gifted students in Konya, took part in the study. Non-gifted students were chosen from the school in which was conducted. 30 students out of 37 who have IQ scores between 105 and 129 were chosen by lot. Since one of the students could not participate in the second cartoon creating activity, study was completed with 29 students.

\subsection{Data Collection}

Data for this study were obtained from the cartoons created by the students. During the data collection process related to creating cartoons based on a joke, gifted and non-gifted students were asked to draw a cartoon that would help reflect the humor in this joke after they were told 'İpe Un Serme', one of Nasreddin Hodja's jokes. In one class period in each group (40 minutes), these jokes were well understood by the students. In the second session one week later, they were asked to create a cartoon for a situation, considering a joke that they would make on 'April 1' in order to collect data related to creating cartoon based on a situation. The obtained products were evaluated in terms of students' cartoons, facts of drawing and expressing humor in their cartoons.

\subsection{Data Collection Tools}

In the study, "Cartoon evaluation rubric" was used as the measurement scale. Cronbach's alpha reliability coefficient of the whole scale was determined as 0,949 . Cronbach's alpha reliability coefficient regarding the five items measuring students' skills of reflecting humor in their cartoons was 0,982; and finally Cronbach's alpha reliability coefficient regarding the six items measuring drawing skills in their cartoons was 0,929 . In the scale development process, the literature review was performed and the cartoon evaluation criteria were determined. The specified criteria were converted into expressions to be used in the scale. The scaled-down expressions were evaluated about whether a cartoon was appropriate in terms of humor, drawing skills and scoring. Furthermore, two visual arts teachers, an academician from the linguistic department, two visual arts and two language arts teachers 
working with gifted students were consulted in order to clarify the expressions. In line with their suggestions, these expressions were corrected. Afterwards, two teachers were asked to score a cartoon. By this means, the applicability of the scale was examined and the scale was put into its final form based on the obtained feedbacks.

While data collection tools were being created, the study determined essential points by a literature review collected opinions about whether or not these points were included in the cartoon evaluation form an on their conformity with the measure principles. The obtained data were subjected to Kappa analysis. The calculated Kappa value as a result of data obtained from the four experts was found 0,66 . Landis and Koch [32] propose that the obtained values $<0$ indicates no agreement and $0-0.20$ slight, $0.21-0.40$ fair, 0.41-0.60 moderate, 0.61-0.80 substantial, and 0.81-1 almost perfect agreement. Considering that value of the cartoon evaluation scale was 0,72 , it can be said that there was a substantial agreement in the results from expert assessment. Following the correction obtained based on the opinions of experts in the field; the scale was put into final form after it was tested on two visual arts teachers and ten students.

In the cartoon evaluation scale, there are eleven expressions such as 'Humor relating to the subject is reflected in the product', 'Different senses of humor relating to the subject are reflected in the products', 'Humor relating to the subject is associated with life in the product, 'There is a sense of humor towards laughter', 'There is a sense of humor towards thinking', 'Elements of art have been used in the product', 'Principles of art have been used in the product', 'The product is effective in terms of technical skill', 'The work is neat and tidy', 'Time has been efficiently used', and 'The product has been made ready for the exhibition'. Five-point Likert item with categories indicated as "Excellent (5)", "Above average (4)", "Average (3)", "Below average (2)", "Very poor (1)" was used for the scoring in the scale. Through the scores obtained from the whole scale, students' achievement scores relating to the cartoon were obtained. Through the items in the scale such as 'Humor relating to the subject is reflected in the product', 'Humor relating to the subject is associated with life in the product', 'There is a sense of humor towards laughter', and 'There is a sense of humor towards thinking', students' scores on reflecting humor in their cartoons were obtained. In order to score the students' drawing skills in the cartoons, the items stating that 'Elements of art have been used in the product', 'Principles of art have been used in the product', 'The product is effective in terms of technical skill', 'The work is neat and tidy', 'Time has been efficiently used', and 'The product has been made ready for the exhibition' were taken into account.

Each cartoon was graded by three academicians regarded as specialists in visual arts. Raters were not informed whether the cartoons belong to the gifted or non-gifted students. The numbered cartoons belonging to each student were individually assessed by each expert. The data were analyzed using the Kappa statistic in order to measure interrater reliability. As a result of the analysis, it was concluded that there was a significant agreement [32] as the Kappa value among the raters which was found 0,76 . The arithmetic mean of the scores given was then taken, and scores for each student were obtained.

\subsection{Data Analysis}

The scores that students obtained from the cartoon evaluation scale were analyzed considering the mean and standard deviations for all the items. Accordingly, the result obtained by dividing the interval (1-5) into five subintervals (options) was indicated as " 1,00 - 1,79 Very poor; 1,80 - 2,59 Below average; 2,60 - 3,39 Average; 3,40 - 4,19 Above average; 4,20 - 5,00 Excellent". Data regarding the other variables about the students were analyzed using descriptive statistics.

In order to determine what techniques would be used in the data analysis process, normal distribution of the group was examined. The obtained results are shown in Table 1.

Table 1. Standard Normal Distribution

\begin{tabular}{|c|c|c|c|c|c|c|}
\hline & \multicolumn{3}{|c|}{ Kolmogorov-Smirnov $^{\mathrm{a}}$} & \multicolumn{3}{|c|}{ Shapiro-Wilk } \\
\hline & Value & $\mathrm{df}$ & $p$ & Value & $\mathrm{df}$ & $p$ \\
\hline non-gifted & 0,225 & 29 & 0,001 & 0,888 & 29 & 0,005 \\
\hline gifted & 0,117 & 30 & $0,200^{*}$ & 0,953 & 30 & 0,210 \\
\hline non-gifted & 0,280 & 29 & 0,000 & 0,766 & 29 & 0,000 \\
\hline as gifted & 0,126 & 30 & $0,200^{*}$ & 0,942 & 30 & 0,106 \\
\hline non-gifted & 0,186 & 29 & 0,011 & 0,905 & 29 & 0,013 \\
\hline gifted & 0,096 & 30 & $0,200^{*}$ & 0,980 & 30 & 0,827 \\
\hline non-gifted & 0,226 & 29 & 0,001 & 0,750 & 29 & 0,000 \\
\hline gifted & 0,067 & 30 & $0,200^{*}$ & 0,986 & 30 & 0,950 \\
\hline non-gifted & 0,397 & 29 & 0,000 & 0,425 & 29 & 0,000 \\
\hline gifted & 0,137 & 30 & 0,156 & 0,960 & 30 & 0,313 \\
\hline non-gifted & 0,083 & 29 & $0,200^{*}$ & 0,980 & 29 & 0,840 \\
\hline gifted & 0,092 & 30 & $0,200^{*}$ & 0,972 & 30 & 0,607 \\
\hline
\end{tabular}


It was checked whether the data analyzed were normally distributed. According to Shapiro-Wilk analysis results, joke-based cartoon scores of the gifted students were calculated as $\mathrm{D} 30=0,953, \mathrm{p}=, 21$; their humor scores in the joke-based cartoon as $\mathrm{D} 30=0,942, \mathrm{p}=0,106$; their drawing scores in the joke-based cartoon as $\mathrm{D} 30=0,980, \mathrm{p}=0,827$, while their scores in the situational cartoons were calculated as $\mathrm{D} 30=0,986, \mathrm{p}=, 950$; their humor scores in the situational cartoons as $\mathrm{D} 30=0,960, \mathrm{p}=0,313$; their drawing scores in the situational cartoons as $\mathrm{D} 30=0,972, \mathrm{p}=0,607$. These results reveal that scores of the gifted students were normally distributed. According to Shapiro-Wilk analysis results, joke-based cartoon scores of the non-gifted students were calculated as $\mathrm{D} 29=0,888, \mathrm{p}=0,005$; their humor scores in the joke-based cartoon as D29 $=0,766$, $\mathrm{p}=0,000$; their drawing scores in the joke-based cartoon as $\mathrm{D} 29=0,905, \mathrm{p}=0,013$, while their scores in the situational cartoons were calculated as $\mathrm{D} 29=0,750, \mathrm{p}=0,000$; their humor scores in the situational cartoons as D29 $=0,425$, $\mathrm{p}=0,000$; their drawing scores in the situational cartoons as $\mathrm{D} 29=0,980, \mathrm{p}=0,840$. These results reveal that scores of the non-gifted students were not normally distributed. According to these results, data regarding the gifted students were analyzed using parametric tests, while data related to non-gifted students were analyzed using non-parametric tests.

\section{Findings/Results}

Students' levels of cartoon drawing were determined by averaging the scores given by the three different specialists based on the cartoons that they created. Data relating to the students' average scores on the cartoon are shown in Table 2.

Table 2. Students' Scores on Creating Cartoon

\begin{tabular}{|c|c|c|}
\hline Cartoons & $\mathrm{X}$ & ss \\
\hline $\begin{array}{c}\text { Joke-based cartoons of the gifted students } \\
\text { Cartoons created by the gifted students based on a given } \\
\text { situation }\end{array}$ & 3,15 & 3,68 \\
\hline $\begin{array}{c}\text { Joke-based cartoons of the non-gifted students } \\
\text { Cartoons created by the non-gifted students based on a } \\
\text { given situation }\end{array}$ & 2,43 &, 56 \\
\hline $\begin{array}{c}\text { give } \\
\text { (1,69 }\end{array}$ &, 55 \\
\hline
\end{tabular}

Expressions indicated as " 1,00 - 1,79 Very poor; 1,80 2,59 Below average; 2,60 - 3,39 Average; 3,40 - 4,19
Above average; 4,20 - 5,00 Excellent" were used as assessment criteria. It is seen from table 2 that for joke-based cartoons, average scores of the gifted students were 3,15 , while their average scores for cartoons based on a given situation were 3,17. Accordingly, cartoons of the gifted students were in medium level. Based on the findings, it can be concluded that the gifted students can create cartoons based on both joke and situation in medium levels. It is seen that for Joke-based cartoons, average scores of the non-gifted students were 2,43, while their average scores for situation-based cartoons were 1,69. Accordingly, abilities of the non-gifted students to create joke-based cartoon were very poor, and their abilities to create cartoons based on a given situation were below average.

As the whole group was not normally distributed, Mann Whitney U Test was used to assess the joke-based cartoons of the gifted and non-gifted students. Related data are shown in Table 3.

Table 3 shows that as a result of the Mann Whitney-U test conducted to determine whether students' scores relating to creating cartoon for assessing their joke-based cartoons differed significantly according to the variable of being gifted, a statistically significant difference was found at $p<0.05$ level in favor of the gifted students among the groups $(U=197, p<0,000)$. Accordingly, it is observed that the gifted students were more successful at creating cartoon relating to a given joke.

Table 3 shows that as a result of the Mann Whitney-U test conducted to determine whether students' scores of using humor in the cartoons they created based on a joke differed significantly from the variable of being gifted, a statistically significant difference was found at $\mathrm{p}<0.05$ level in favor of the gifted students among the groups $(\mathrm{U}=219,5, \mathrm{p}<0,000)$. Accordingly, it is observed that the skills of the gifted students to use humor in the cartoons relating to a given joke were better.

Table 3 shows that as a result of the Mann Whitney-U test conducted to determine whether students' drawing scores relating to the cartoons they created based on a joke differed significantly from the variable of being gifted, a statistically significant difference was found at $\mathrm{p}<0.05$ level in favor of the gifted students among the groups $(\mathrm{U}=252, \mathrm{p}<0,000)$. Accordingly, it is observed that drawing skills of the students identified in the cartoons they created based on a given joke were better.

Table 3. Assessment of Joke-Based Cartoons of the Gifted and Non-Gifted Students

\begin{tabular}{|c|c|c|c|c|c|c|c|}
\hline Based on a joke & Groups & $\mathrm{N}$ & S.O & S.T & $\mathrm{U}$ & $\mathrm{z}$ & $\mathrm{p}$ \\
\hline \multirow{2}{*}{ Creating cartoons } & gifted & 29 & 21,79 & 632,00 & \multirow{2}{*}{197} & \multirow{2}{*}{$-3,609$} & \multirow{2}{*}{$0,00^{*}$} \\
\hline & non-gifted & 30 & 37,93 & 1138,00 & & & \\
\hline \multirow{2}{*}{ Humor in the cartoon } & non-gifted & 29 & 22,57 & 654,50 & \multirow{2}{*}{219,5} & \multirow{2}{*}{$-3,270$} & \multirow{2}{*}{$0,00^{*}$} \\
\hline & gifted & 30 & 37,18 & 1115,50 & & & \\
\hline \multirow{2}{*}{ Drawing in the cartoon } & non-gifted & 29 & 23,69 & 687,00 & \multirow{2}{*}{252} & \multirow{2}{*}{$-2,776$} & \multirow{2}{*}{$0,00^{*}$} \\
\hline & gifted & 30 & 36,10 & 1083,00 & & & \\
\hline
\end{tabular}


As the whole group was not normally distributed, Man Whitney U Test was used to assess the situational cartoons of the gifted and non-gifted students. Related data are shown in Table 4.

Table 4 shows that as a result of the Mann Whitney-U test conducted to determine whether students' scores relating to creating a situational cartoon differed significantly from the variable of being gifted, a statistically significant difference was found at $p<0.05$ level in favor of the gifted students among the groups $(\mathrm{U}=67, \mathrm{p}<0,000)$. Accordingly, it is observed that the gifted students were more successful in creating cartoon relating to a given situation.

Table 4 shows that as a result of the Mann Whitney-U test conducted to determine whether students' scores of using humor in their situational cartoons based on a case differed significantly from the variable of being gifted, a statistically significant difference was found at $p<0.05$ level in favor of the gifted students among the groups
( $U=63, p<0,000$ ). Accordingly, it is observed that the skills of the gifted students to use humor in the cartoons relating to a given situation were better.

Table 4 shows that as a result of the Mann Whitney-U test conducted to determine whether students' drawing scores relating to the cartoons they created based on a situation differed significantly from the variable of being gifted, a statistically significant difference was found at $\mathrm{p}$ $<0.05$ level in favor of the gifted students among the groups ( $U=98, p<0,000$ ). Accordingly, it is observed that drawing skills of the students identified in the cartoons they created based on a given situation were better.

As this group was not normally distributed, the Wilcoxon signed-rank test, one of the non-parametric tests, was used to understand whether there was a difference in skills of drawing cartoons, using humor and drawing in the cartoons the non-gifted students created based on a joke and a given situation. The obtained data are shown in Table 5 .

Table 4. Assessment of the Situational Cartoons of the Gifted and Non-Gifted Students

\begin{tabular}{|c|c|c|c|c|c|c|c|}
\hline Based on a situation & Groups (Students) & $\mathrm{N}$ & S.O & S.T & $\mathrm{U}$ & $\mathrm{z}$ & $\mathrm{p}$ \\
\hline \multirow{2}{*}{ Creating cartoons } & non-gifted & 29 & 17,31 & 502 & \multirow{2}{*}{67} & \multirow{2}{*}{$-5,582$} & \multirow{2}{*}{$0,00^{*}$} \\
\hline & gifted & 30 & 42,27 & 1268 & & & \\
\hline \multirow{2}{*}{ Humor in the cartoon } & non-gifted & 29 & 17,17 & 498 & \multirow{2}{*}{63} & \multirow{2}{*}{$-5,513$} & \multirow{2}{*}{$0,00^{*}$} \\
\hline & gifted & 30 & 42,40 & 1272 & & & \\
\hline \multirow{2}{*}{ Drawing in the cartoon } & non-gifted & 29 & 18,38 & 533 & \multirow{2}{*}{98} & \multirow{2}{*}{$-5,113$} & \multirow{2}{*}{$0,00^{*}$} \\
\hline & Gifted & 30 & 41,23 & 1237 & & & \\
\hline
\end{tabular}

$\mathrm{p}=0,05$

Table 5. Assessment of the Cartoons of the Non-Gifted Students Relating to a Joke and a Given Situation

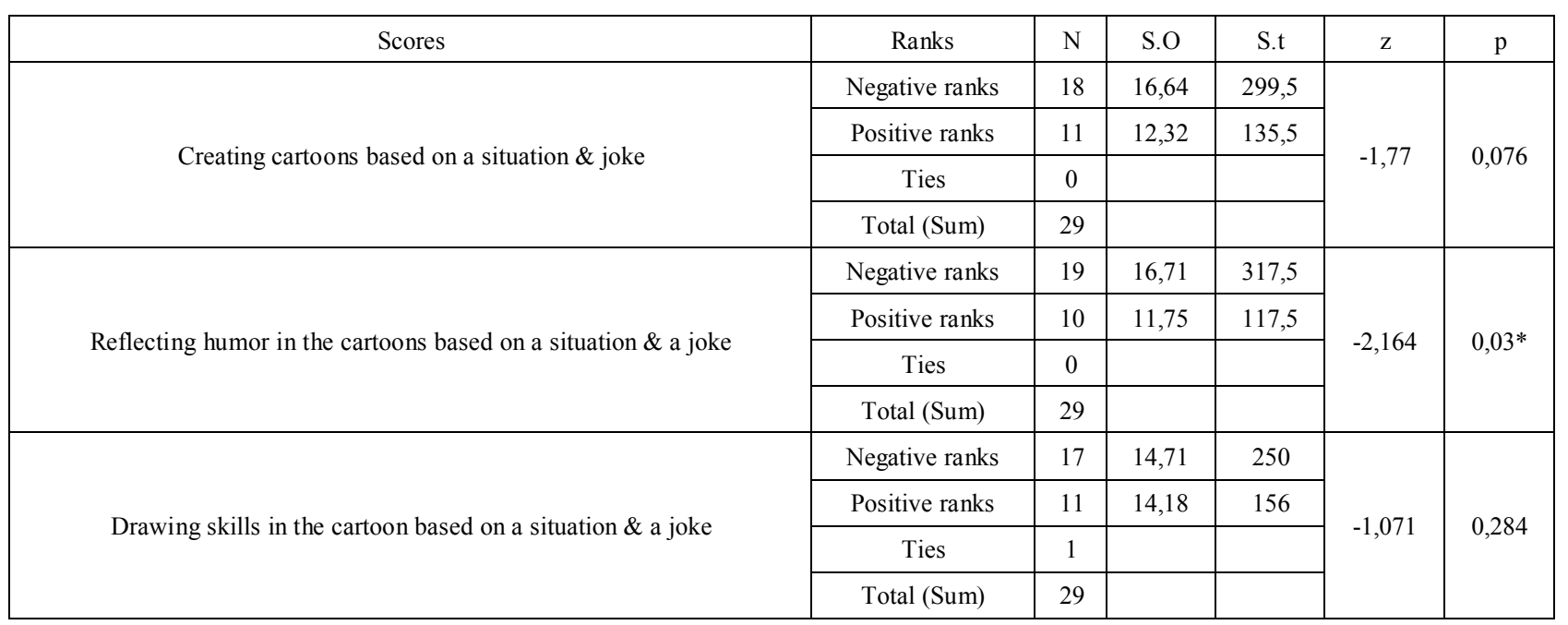


Table 5 shows that as a result of the Wilcoxon signed-rank test conducted to determine whether there was a significant difference between cartoon creation scores of the non-gifted students based on a situation and a joke, no statistically significant difference was found at $p<.005$ level among the average rank scores $(z=-1,77 ; p=0,076)$. Accordingly, it is observed that the non-gifted students achieved the same level of success in terms of creating a cartoon based on both a situation and a joke.

Table 5 shows that as a result of the Wilcoxon signed-rank test conducted to determine whether there was a significant difference between students' (non-gifted) scores of reflecting humor in the cartoons based on a situation and a joke, a statistically significant difference was found at $\mathrm{p}<.005$ level among the average rank scores $(\mathrm{z}=-2,164 ; \mathrm{p}=0,03)$. The difference mentioned above was found in favor of joke-based cartoons. Accordingly, it is observed that the non-gifted students achieved more success in terms of reflecting humor in their joke-based cartoons.

Table 5 shows that as a result of the Wilcoxon signed-rank test conducted to determine whether there was a significant difference between the drawing scores on the situation and joke-based cartoons of the non-gifted students, no statistically significant difference was found at $\mathrm{p}<.005$ level among the average rank scores $(\mathrm{z}=-1,071$; $\mathrm{p}=0,284)$. Accordingly, the non-gifted students achieved the same level of success in terms of drawing skills in their cartoons based on both a situation and a joke.

As the group was normally distributed, data were analyzed using " $t$ test" to understand whether there was a difference between skills of drawing cartoons, using humor and drawing in the cartoons the gifted students created based on a joke and a given situation. The obtained data are shown in Table 6.
It is seen from table 6 that average scores (based on a given joke) of the gifted students were 3,15 , while their average scores for cartoons based on a given situation were 3,17 . Accordingly, the difference between the cartoon scores based on a given situation and those based on a joke was not found to be statistically significant $(t=-, 109, p>$, 05). In summary, it is observed that there was no statistically significant difference between cartoon scores (based on a situation) of the gifted students and their scores based on a joke.

It is seen from table 6 that average scores of the gifted students about reflecting humor in their cartoons based on a given joke were 3,16 , while their average scores about reflecting humor in their cartoons based on a situation were 2,99 . Accordingly, the difference between their scores relating to reflecting humor in the cartoons based on a given situation and those relating to reflecting humor in the cartoons based on a joke was not found to be statistically significant $(t=, 644, p>, 05)$. In summary, it is observed that there was no statistically significant difference between the scores of the gifted students about reflecting humor in the situational cartoons and those relating to reflecting humor in the joke-based cartoons.

As seen in table 6, drawing score averages of the gifted students in the cartoons based on a given joke were 3,15, while their score averages in the cartoons based on a situation were 3,33. Accordingly, the difference between the drawing scores in the cartoons based on a situation and those in the cartoons based on a joke was not found to be statistically significant $(t=-1,012, p>, 05)$. In summary, it is observed that there was no statistically significant difference between drawing scores of the students in the cartoons based on a situation and their drawing scores in the cartoons based on a joke.

Table 6. Analysis of the Cartoons the Gifted Students Created Based on a Joke and a Given Situation

\begin{tabular}{|c|c|c|c|c|c|c|c|}
\hline & & $\mathrm{N}$ & $\mathrm{X}$ & ss & $\mathrm{sd}$ & $\mathrm{t}$ & $\mathrm{p}$ \\
\hline \multirow{2}{*}{ Creating cartoon } & In the cartoons based on a joke & 30 & 3,15 & 0,67 & 29 & \multirow{2}{*}{$-0,109$} & \multirow{2}{*}{0,91} \\
\hline & In the cartoons based on a situation & 30 & 3,17 & 0,55 & & & \\
\hline \multirow{2}{*}{ Using humor in the cartoon } & In the cartoons based on a joke & 30 & 3,16 & 0,95 & 29 & \multirow{2}{*}{0,644} & \multirow{2}{*}{0,52} \\
\hline & In the cartoons based on a situation & 30 & 2,99 & 0,80 & & & \\
\hline \multirow{2}{*}{ Drawing skills in the cartoon } & In the cartoons based on a joke & 30 & 3,15 & 0,76 & 29 & \multirow{2}{*}{$-1,012$} & \multirow{2}{*}{0,32} \\
\hline & In the cartoons based on a situation & 30 & 3,33 & 0,61 & & & \\
\hline
\end{tabular}




\section{Conclusions, Discussion and Recommendations}

When the results are analyzed, it is observed that average scores of the gifted students in the cartoons based on a joke was 3,15 , and their average scores based on a situation was 3,17 , while average scores of the non-gifted students in the cartoons based on a joke was 2,43 , and their average scores in the cartoons based on a given situation was 1,69 . As explained previously, considering that the results obtained by dividing the interval (1-5) into five subintervals (options) were indicated as " $1,00-1,79$ Very poor; $1,80-2,59$ Below average; 2,60 - 3,39 Average; 3,40 - 4,19 Above average; 4,20 - 5,00 Excellent", cartoon drawing skills of the gifted students were at a medium level. But cartoon drawing skills of non-gifted students were below average.

When taken into consideration that the students are fourth graders, it can be said that drawing cartoons at a medium level is an important level for the gifted students. Considering that the gifted students think clearly, develop their relationships easily, transfer their knowledge and use them in the most appropriate way in new situations [3] and they are adept at making jokes and witty remarks [10], it is not surprising that the gifted students are more successful at creating cartoons. No studies have found the cartoon drawing skills of the gifted students. However, this fact has been actually revealed via this study. According to the result obtained from this study, activities towards understanding cartoons, identifying the basic components of cartoons such as humor and drawing and also developing skills on this matter can be included in the educational process of the non-gifted students. Training programs relating to cartoon can be started when the gifted students are 9-10 years old. Based on the fact that cartoons of these students are above average and their ability to understand a cartoon is also better, cartoons can be used as a teaching tool.

The gifted students have achieved the same level of success both in the situational cartoons and in the joke-based cartoons. The key element of cartoon is imagination [13]. It is known that the gifted students have abstract [12], creative and imaginative thinking skills. Boland [33] indicates that art-specific works of the gifted (talented) include unusually dynamic and intuitive quality of imagination. A performance carried out with reference to a case in which an advanced imagination is allowed also brings success. It is indicated that a cartoon is a drawing in which children comment by establishing a connection, and weave a cognitive story by detecting differences and similarities between objects [15].

Moreover, the gifted students hold strong opinions and thoughts, and come up with solutions by producing unusual ideas [9]. It is known that gifted students have a sense of humor [10], and they have the ability to understand jokes and humor maturely, and to see the funny side of something and its strangeness [11]. They learn to make mature and funny jokes and enjoy them, and use appropriate humor at an early age [3]. Therefore, whether the gifted students are given a concrete and true story or a joke that includes more abstract and hidden humor, their abilities to create cartoons do not change. This fact shows that jokes and humorous situations can be used on the same level in the cartoon activities of the gifted students. For this reason, while performing cartoon activities with gifted students, as jokes can be used, situations that students have created or current humorous events can also be used. It can be said that identifying the ones having special talent about creating cartoon in the educational process of the gifted students is of importance for training skilled cartoonists. It can also be said that reflecting humor in a cartoon is a sign of superior intelligence. While on the one hand, imaginations, senses of humor and editing skills of the gifted students are improved in order to increase their cartoon achievement, on the other hand they should be given more chances to experience activities for creating cartoons more often. While performing activities for cartoon training with gifted students, jokes that include more hidden elements of humor can also be used as well as the true events.

It is seen that successful use of humor by gifted students has positively affected the cartoons. It was observed that the gifted students are also successful at reflecting humor in their cartoons based on a joke and a situation. Coşar [17] remarks that there is a natural connection in terms of humor between cartoon and literary genres (joke, short story, novel, theater, poetry and essays etc.), in which humorous expression comes to the fore. Boland [33] also emphasizes the dynamic and intuitive quality of imagination of these students. The gifted students put their vivid imaginations into effect as well while producing literary works, which also increases the quality of their products.

It is known that besides having a general mental ability, the gifted students are skilled in many fields as well [34]. For this reason, they also have superior talents in visual and performing arts. The results of this study indicate that the gifted students are more successful than the non-gifted students in terms of their drawing skills. Meanwhile, the gifted students have achieved the same level of success both in the joke-based cartoons and in the situational cartoons in terms of drawing skills. It is known that students regarded as gifted are not only academically successful but they are also talented in art (painting) [35].

The non-gifted students are, in general, more successful in the joke-based cartoons in comparison with their cartoons based on a given situation. Meanwhile, they have relatively reflected the humor better in the cartoons they created based on a joke. In addition, their drawing skills are in the same level in the cartoons based on a given situation and a joke. This fact can be interpreted such that the non-gifted students understand the humor better which emerges more clearly in a joke, but they could have difficulty in creating humor and cartoon with reference to a 
given situation. When taking into consideration that these students who are fourth-grade primary school pupils are in the concrete operational stage [29], it may be said that they can cartoon by understanding better with reference to a joke, but they have trouble caricaturizing based on a given situation. Therefore, it is thought that it would be more useful to start cartoon drawing activities conducted with non-gifted students with the jokes and subjects based on concrete events.

\section{REFERENCES}

[1] G. Clark \& E. Zimmerman. Issues and practices related to identification of gifted and talented students in the visual arts, Bloomington: Indiana University, 1992.

[2] J. S. Renzulli. What makes giftedness, Phi Delta Kapan, Vol. 60, No. 3, 180-186, 1978.

[3] F. Akarsu. Üstün yetenekliler, Şirin M. R., Kulaksızoğlu A., Bilgili A. E. (Ed.). Üstün yetenekli çocuklar seçilmiş makaleler itabı, (127-154). İstanbul: Çocuk Vakfı, 2004.

[4] H. Akkanat. Üstün veya özel yetenekliler, Şirin M. R., Kulaksızoğlu A., Bilgili A. E. (Ed.). Üstün yetenekli çocuklar seçilmiş makaleler kitabı, (169-193). İstanbul: Çocuk Vakfi, 2004.

[5] T. Stuart \& A. Beste. Farklı olduğumu biliyordum, Gönenli A. (Çev.), Ankara: Kök, 2008.

[6] D. A. Sisk. The state of gifted education: toward a bright future. Music Educators Journal, Vol. 76, No. 7, 35-39, 1990.

[7] H. Darga. İlköğretim 1. sinıfta saptanan üstün yetenekli çocuklara ve sınıf arkadaşlarına uygulanan zenginleştirme programını çoklu zekâ alanlarındaki performans düzeylerini arttırmaya etkisi, Yayımlanmamış doktora tezi, Gazi Üniversitesi Eğitim Bilimleri Enstitüsü, Ankara, 2010.

[8] R. Peiffer \& N. Mulqueen. Maryland classroom gifted education, Publication from the Maryland State Department of Education, Maryland, Vol. 14, No. 1, 1-4, 2008.

[9] CCEA (Council of curriculum, examinations and assessment). Gited and talented children in (and out) of the classroom, 29 Ocak 2012 tarihinde www.nicurriculum.org.uk adresinden erişildi, 2006.

[10] A. Hurwitz \& M. Day. Children and their art methods fort the elementary school (7th Edition), Orlando: Harcourt College publishers, 2001

[11] Ü. Davaslıgil. Üstün yetenekli çocukların özellikleri ve bu çocukların ailelerinin karşılaşabileceği sorunlar, Aysan F (Ed.), Üstün veya Özel Yetenekli Öğrencilerin Eğitimi Paneli, (8-22), İzmir, 2004.

[12] A. Ataman. Üstün zekâlılar ve üstün yetenekliler, Eskişehir: Anadolu Üniversitesi yayını, 1998.

[13] M. Bakır. Grafik sanatında yaratıcılık ve karikatür ilişkisinin sanat eğitimine etkisi, Yayımlanmamış yüksek lisans tezi, Gazi Üniversitesi Eğitim Bilimleri Enstitüsü, Ankara, 2008.
[14] H. McBride \& G. Verbeck. Technical tendencies of caricature, The Monthly Illustrator, Vol. 4, No. 13, 215-219. 1895.

[15] F. Seçgin \& G. Yalvaç \& T. Çetin. İlköğretim 8. sınıf ögrencilerinin karikatürler aracılığıyla çevre sorunlarına ilişkin algıları, İnternational conference on new trends in education and their implications, (391-398), Antalya, 2010.

[16] E. Özşahin. Karikatürlerle coğrafya öğretimi, Marmara Coğrafya Dergisi, Vol.20, 20, 101-122, 2009.

[17] S. Coșar. Edebiyatın karikatürize halleri, Literature And History of Turkish 0r Turkic, Vol. 5, No. 2, 688- 734, 2010.

[18] İ. Yardımcı. Mizah kavramı ve sanattaki yeri, Uşak Üniversitesi Sosyal Bilimler Dergisi, Vol. 3, No. 2, 1-41, 2010.

[19] D. Barut \& B. Akbaba. The effect of using cartoon in 6th grade social studies course on creative thinking skills, Anadolu Kültürel Araştırmalar Dergisi, (Vol. 1, No. 1, 51-69, 2017.

[20] H. Yaman. Cartoons as a teaching tool: a research on Turkish language grammar teaching, Educational Sciences: Theory \& Practice, Vol. 10, No. 2, 1215-1242, 2010.

[21] İ. Yüksel \& A. Adıüzel. Use of cartoons in values education: sample of social unity and solidarity values, Sakarya University Journal of Education, Vol. 2, No. 3, 68-80, 2012.

[22] A. F. Ersoy \& B. Türkkan. Analyzing social and environmental issues elementary school students reflect in their cartoons, Vol. 35, No. 156, 96-109, 2010.

[23] D. Melanlığlu \& E. Karakuş \& B. Özdemir. The use of cartoons in teachıng Turkish as a foreın language, Mustafa Kemal University Journal of Social Sciences Institute, Vol. 9, No. 19, 241-256, 2012.

[24] U. Sak. Üstün zekâlı çocukların tanılanması, Ayşegül A., Yurdagül A., Necati B. (Ed.). Üstün Yetenekli Çocukların Eğitim Semineri 3-7 Eylül Kuşadas1, Ankara: Sentez Matbac1lik, 61-93, 2007.

[25] S. Tarhan \& S. Kılıç. Identification of gifted and talented student and models in turkey, Journal of Gifted Education Research, Vol. 2, No. 2, 27-43, 2014.

[26] M. Enç. Üstün beyin gücü gelişim ve eğitimleri. Ankara: Gündüz Eğitim ve Yayıncılık, 2005.

[27] A. Ataman. Üstün yetenekli çocuklar ve zenginleştirme. Ayşegül A., Yurdagül A., Necati B. (Ed.). Bilim ve Sanat Merkezlerinde Görevli Öğretmenlerin Mesleki Niteliklerinin Artırılması Semineri, Üstün Yetenekli Çocukların Eğitim Semineri 3-7 Eylül Kuşadası, Ankara: Sentez Matbacilik, 13-60, 2007.

[28] A. Yıldırım \& H. Şimşek. Sosyal bilimlerde nitel araştırma yöntemleri (2. Bask1), Ankara: Seçkin, 2000.

[29] N. Senemoğlu. Gelişim öğrenme ve öğretim, Ankara: Ertem Matbaacilik, 1997.

[30] M. Q. Patton. Qualitive research and evaluation methods. (3. Edition). Thousand Oaks, CA: Sage, 2002.

[31] M. Q. Patton. Qualitive evaluation and research methods. (2. Edition). Newbury Park, CA: Sage, 1990. 
[32] J.R. Landis \& G.G. Koch. The measurement of observer agreement for categorical data, Biometrics, Vol. 33, 159174, 1977.

[33] D. Boland. Artistically talented students: a call for research, Working Papers in Art Education, Vol.5, No.1, 16-25, 1986.

[34] A. Ataman. Üstün zekâlı ve üstün özel yetenekli çocuklar,
Şirin M. R., Kulaksızoğlu A., Bilgili A. E. (Ed.). Üstün yetenekli çocuklar seçilmiş makaleler kitabı, (155-168). İstanbul: Çocuk Vakfı, 2004.

[35] G. Clark \& E. Zimmerman. Nurturing the arts in programs for gifted and talented students, Phi Delta Kapan, Vol. 79, No. 10, 746-751, 1998. 